\title{
Chronic diseases, social context and adolescent health
}

\author{
Luísa Barros*; Margarida Gaspar de Matos**; Joan M. Batista-Foguet*** \\ *Health Psychologist, Faculdade de Psicologia e Ciências da Educação, University of Lisbon, \\ Portugal \\ **Health Psychologist, Faculdade de Motricidade Humana, Technical University of Lisbon, Portugal \\ ${ }^{* * *}$ Statistics Methods Professor Professor, ESADE BS. Universidad Ramon Llull, Barcelona, Spain \\ Endereço para correspondência
}

\begin{abstract}
Studies have claimed children with chronic diseases to have greater probability of behavioural and emotional problems, while others have emphasized good adaptation of most children. Protection and risk factors were identified as determinants of positive adaptation to chronic conditions, such as family and school related dimensions. This study tested the negative association between a chronic disease and positive health. A nationally representative sample of 6131 Portuguese adolescents, mean age 14, was surveyed based on a self-completed questionnaire. We used data from the Portuguese study of the 2002 HBSC (Health Behaviour in School-Aged Children), namely the questions on chronic disease, demographics, psychological symptoms, school life related variables, substance use and life satisfaction. Preliminary multilevel analysis and Structural Equation Model were specified. Students with chronic disease reported more psychological symptoms, less global satisfaction and less positive perception of school environment. Results supported the assumption that chronic disease is negatively associated with adolescent global life satisfaction, and that this relation is moderated by gender, school grade and socioeconomic status, and mediated by variables related with the school. The data supports a recommendation for schools to develop more systematic procedures to attend students with chronic conditions.
\end{abstract}

Keywords: Chronic diseases, Adolescence, Positive health.

\section{RESUMO}

As crianças com doença crónica têm maior probabilidade de apresentar problemas emocionais e comportamentais, embora alguns estudos apontem a sua boa adaptação. Foram identificados factores de protecção e de risco para a adaptação positiva a condições crónicas relacionados com a família e a escola. Este estudo testou a associação negativa da doença crónica à saúde positiva. Uma amostra nacionalmente representativa de 6131 adolescentes portugueses com média de idade de 14 anos foi avaliada através de um questionário auto-administrado. Usámos dados do estudo português do HBSC de 2002 (Health-Behaviour in School-Aged Children), nomeadamente as questões sobre doença crónica, indicadores demográficos, sintomas psicológicos, variáveis relacionadas com a vida escolar, uso de substâncias e satisfação com a vida. Realizamos análises

REVISTA BRASILEIRA DE TERAPIAS COGNITIVAS, 2008, Volume 4, Número 1 
multivariadas, seguidas da especificação dum Modelo de Equações Estruturais. Estudantes com doença crónica relataram mais sintomas psicológicos, menor satisfação global e menos percepção positiva do ambiente escolar, confirmando a associação negativa entre a doença crónica e a satisfação global com a vida, e que esta relação é moderada pelo género, ano de escolaridade e estatuto sócio-económico, e mediada por variáveis relacionadas com a escola. Recomenda-se, pois, que as escolas desenvolvam procedimentos mais sistemáticos para apoiar os estudantes com doença crónica.

Palavras-chave: Doenças crónicas, Adolescentes, Saúde positiva.

\section{Introduction}

Historically, research about children with chronic diseases has searched for differences between healthy and chronically ill children, or between children with different medical conditions, assessing the prevalence of psychological distress, namely behavioural or emotional disturbances in several groups characterized by disease and age (Creer, 1982; Varni \& Wallander, 1988). In the past, several studies have claimed that children with chronic diseases have a greater probability of presenting behavioural and emotional problems (Harbeck-Weber \& McKee, 1995; Starfield \& Riley, 1998; Wallander \& Varni, 1992), while others have emphasized the good adaptation of most children (Kazak, 1992).

These results, though somehow contradictory and inconclusive (Combs-Orme, Helfinger \& Simpkins, 2002), alerted professionals to the greater probability of mental health problems in children with chronic conditions, both as internalizing and externalizing disturbances (American Academy of Pediatrics, 1993), body dissatisfaction and unhealthy weight-control practices (Neumark-Sztainer, Story, Resnick, Garwick, \& Blum, 1995).

A recent meta-analysis (Barlow \& Ellard, 2006) revealed that children with chronic illness were at slightly higher risk of psychosocial distress, although only a minority experienced clinical symptoms. Children with diabetes, asthma and cystic fibrosis reported worse health related quality of life than a control of healthy children (Sawyer et al., 2004). Also, there has been a greater awareness of the special health needs of these youngsters that go further than adaptation to the special life conditions imposed by illness (Miller, Recsky \& Armstrong, 2004), and consequently more attention has been directed to the assessment of positive dimensions of adaptation, such as happiness or wellbeing (Barlow \& Ellard, 2006). Some recent work points out that children with chronic conditions may have as much or even greater probability for placing themselves in risky situations (Miauton, Narring \& Michaud, 2003), or engage in risk behaviours such as suicide attempts, alcohol, tobacco and marijuana consumption (Blum, Kelly \& Ireland, 2001), than their healthy peers.

Presently there is a large consensus to view the presence of chronic medical conditions as a stressor that will interact with other risk and protective factors to explain child and family adaptation (Suris, Michaud, \& Viner, 2004; Wallander, 2001). Researchers aim to identify positive ways of adaptation to the different challenges posed by the diagnostic, treatment and consequences of diseases so that effective interventions can be developed to foster wellbeing (Miller et al., 2004).

Several protection and risk factors were identified as important determinants of a positive adaptation to chronic conditions, namely family and school related dimensions (Wallander, 2001). Families of chronically ill children face very important challenges and often experience high levels

REVISTA BRASILEIRA DE TERAPIAS COGNITIVAS, 2008, Volume 4, Número 1 
of stress (American Academy of Pediatrics, 1993; Coffey, 2006; Drotar, 1997; Rao, Pradhan \& Shah, 2004) that can contribute to emotional and behavioural problems in these children (Brannan, Heflinger \& Bickman, 1997). The role of parents in promoting their child's positive adaptation to chronic conditions is emphasized (Edwards \& Davis, 1997, Seiffge-Krenke, 2001). School emerges as the other important context of adaptation, as both academic success and peer acceptance are important contributors to wellbeing (Suris et al., 2004). School absenteeism may be an important mediator of this association (Westborn, 1992).

The aim of this study is to verify the negative relationship between chronic disease and a composite measure of global life satisfaction (life satisfaction and happiness) in a nationally representative sample of Portuguese adolescents. Furthermore we intended to assess how this possible association is moderated by gender, school grade and socio economic status, and the role of family and school as mediators of the relationship of chronic diseases with global life satisfaction. It was predicted that the existence of chronic disease would be associated with adolescent global satisfaction, but that the addition of a set of ecologic variables (family, peers and school) would mediate this relationship.

\section{Methods}

Participants and sampling methods

The Portuguese survey reported in this study is a component of the Health Behaviour in SchoolAged Children (HBSC) study (Currie, Hurrelmann, Settertobulte, Smith \& Todd, 2000; Currie, Samdal, Boyce \& Smith, 2001; Currie et al., 2004). Portugal was included as a full partner for the first time in 1996 (Matos \& Aventura Social, 2004).

This survey is based on a self-completed questionnaire that is administered in schools by teachers, in the classroom. The Portuguese HBSC survey included pupils in the 6th, 8th and 10th years of high school $(M=14 ; S D=1.85)$. The National sample consisted of 6131 students from 125 randomly chosen Portuguese schools, representing the entire country as stratified by Education Regional Divisions. Geographically, pupils were distributed as follows: North: $42.9 \%$, Centre: 17.7\%, Lisbon: $30.7 \%$, Alentejo: $4.1 \%$, and Algarve: $4.5 \%$. From these 6131 pupils, 51\% were girls and $49 \%$ boys, and were distributed as follows: $38.6 \%$ in the 6 th grade, $35.6 \%$ in the 8 th grade and $25.8 \%$ in the 10 th grade. The sampling unit used in this survey was the class. In each school, classes were randomly selected in order to meet the required number of students for each grade, which was proportional to the number of same grade mates for each specific region, according to the numbers provided by the Ministry of National Education. Children's participation in the survey was voluntary. Children who were absent from school on the day of the survey were not included. Pupils' completion of questionnaires was voluntary and anonymity was assured. $87 \%$ of the students responded.

This study followed strictly the norms from the Helsinki declaration and advice at the University board level and all authorizations at the Educational Divisions, school and parents level were obtained.

The questionnaire

The questionnaire included questions on demographics (gender, school grade and socio-economic status), school environment, tobacco and alcohol use, aspects of psychosocial health, general health symptoms, social relations, social support and chronic diseases.

For the purpose of this study, the group of pupils with a chronic disease $(n=356 ; 5.8 \%$ of the total population; Mean Age $=13.48$; girls $=44.9 \%$ and boys $=55.1 \%$ ) was formed by those who answered "Yes" to the question: "Do you have any health problem that prevents you from doing things that others in your age group do?" And that, to a second question "If YES, what is this problem?"

REVISTA BRASILEIRA DE TERAPIAS COGNITIVAS, 2008, Volume 4, Número 1 
ticked the answer "A chronic disease (such as diabetes, asthma, epilepsy)", which was one of the alternatives. The other alternative was "sensory or motor deficits".

Data Analysis

Variables in study were scale variables and were quantified using an optimal scaling procedure (Batista-Foguet, Fortiana, Currie \& Villalbi, 2004), and thus dealt with as continuous variables. An imputation procedure allowed the inclusion of the entire sample, for the purposes of the proposed structural equation models.

Besides reporting or not a chronic disease, variables included demographics (gender, school grade, socio economic status), psychological symptoms (feeling low, feeling angry, feeling nervous, feeling tired), school life related variables (school capacity, feelings towards school, peer acceptance, teacher available to help when necessary), substance use (tobacco consumption, spirits consumption, drug consumption in the previous month), and a composite measure of global life satisfaction (life satisfaction [Cantril,1965], and feeling happy).

\section{Results}

After a preliminary multilevel analysis, using the variable global life satisfaction as a dependent variable, a Structural Equation Model (SEM) was specified for correcting for measurement error. F. Lisrel 8.71 was used to perform this last analysis (Jöreskog, Sörbom, du Toit \& du Toit, 1999). Missing data was considered "missing at random", following recommendations from Graham, Hofer and Mackinnon (1996), and was imputed based on multiple regression estimates with an added random component available in SPSS Package (version 13.0). Different adjustment indexes were used to assess the model goodness of fit. The measurement model includes the following five factors (loadings between brackets): "consumption" including consumption of tobacco (.622) and spirits (.780), "global life satisfaction" including life satisfaction (.658) and happiness (.782), "psychological symptoms" aggregating feeling "low" (.777), feeling angry (.546) and feeling nervous (.508), some " school related variables" aggregating feelings towards school (.572), perception of school capacity (.304) and perception of teachers help (.417), "social economic status (SES)" including father professional status(1) and father formal education (.534). The following variables were also included: "social acceptance by peers" in school, "gender", "reporting a chronic disease" and "school grade"(used as a proxy for age).

The structural model showed a significant standardized effect on "global life satisfaction" from (absence of) psychological symptoms (.344), (positive) school environment (.420), social acceptance by peers in school (.344), (not) reporting a chronic disease (.078), gender (being a male) $(-.113)$ and (lower) school grade (-077). The explained variance of "global life satisfaction" was $59.6 \%$.

This model showed adequate adjustment indexes, Root Mean Square Error of approximation (RMSEA $=.0441 ; 90 \%$ CI $=.0417-.0465)$, Standardized Root Mean Square Residual $(R M R=$. 0357), Goodness of Fit Index (GFI = .978) and Adjusted Goodness of Fit Index (AGFI = .965).

Further analysis of the standardized regression matrix on reporting a chronic disease, revealed a significant association between reporting a chronic disease and global life satisfaction $(r=.208)$, psychological symptoms (.196) and school related variables $(r=.151)$ and no significant association between reporting a chronic disease and consumptions.

\section{Discussion}

Students in the chronic disease group were more frequently in the 6th grade $(43.8 \%)$, than in 8 th grade $(35.7 \%)$ and in 10 th grade $(20.5 \%)$. There is no clear epidemiological evidence of a 
relevant chronic disease status decrease with school grade, which can be considered a rough proxy for age, here considered because a "cluster effect" of age group was searched, which could be affected if the variable age was considered. Thus, this decrease pattern of chronic disease by school grade that was found can be better explained, at least in the Portuguese population, by the increase of drop outs whenever pupils have relevant health difficulties, as an important number of children still don't complete compulsory formal education. Another possibility that should be considered and further studied is that older adolescents may be more reluctant to define themselves as having a chronic disease.

Overall, students with a chronic disease report more psychological symptoms, less global satisfaction and less positive perception of school environment, confirming some previous data (Barlow \& Ellard, 2006; Sawyer et al., 2004). Other studies have shown that youngsters who report a chronic disease seem to be in special risk for psychological and school adaptation, indicating that their special needs are probably not being fully met (Seiffge-Krenke, 2001). They seem to need further support in finding alternative ways of adapting to the special conditions and limitations of their disease, and more supportive teacher relationships. Taken together, these results support the assumption that youngsters with a chronic illness are at risk for overall poorer adaptation and health, and that the school environment and the teachers' role deserve more attention in the context of health and education systems (Miller et al, 2004).

This population of young adolescents with a chronic illness doesn't seem to be more careful in avoiding tobacco and spirits, in spite of their increased short term vulnerability to these toxic substances, which emphasizes the importance of taking special care with health education actions. But, contradicting somehow other studies that have found significant differences in substance consumption or risky behaviour in adolescents with and without chronic conditions (Miauton et al., 2003; Blum et al., 2001; The McCreary Centre Society, 1993), chronic disease is not associated with more frequent consumption of tobacco or alcohol. This may be accounted by differences in the definition of chronic conditions, here referring only to somatic diseases, while in other studies sensory, motor or learning disabilities were included. Also, studies including older youngsters, who are more frequently involved in health risk behaviours, may be more sensitive to differences between healthy and ill adolescents' life styles.

Notwithstanding some limitations, due to the variables used in this study being developed post hoc from an existing survey (the major one being the limited number of questions about chronic condition, and the fact that chronic condition is, in this study, a self-perception) this study used a large sample of adolescents and the sampling procedures ensured a nationally representative sample. Description of calculations about representativity of HBSC national samples was detailed in Currie et al. (2000). Moreover, this study is one of the few investigations about the effects of chronic health conditions and life satisfaction, and the mediating role of school environment, that we know about.

In spite of the limitations of this study, we can interpret this data as a strong recommendation for schools to pay special attention to students with chronic conditions. Schools can play a supportive role to these youngsters and their families, contribute to a timely identification of those students at special risk for adjustment problems and supply interventions directed to the enhancement of social and coping skills.

Schools can be a suitable environment to aid children in the development of positive peer relationships (Harbeck-Weber \& McKee, 1995, Schmoyer, 2007). Teachers may need assistance with obtaining health-related information and become more proactive in identifying the educational implications and special needs of students' chronic illness (Mukherjee, Lightfoot \& Sloper, 2000). Also, they should be encouraged to assume a supporting role with these children, namely by learning more about chronic conditions and about the social skills and coping strategies that have proved useful in these situations. Further studies with population based samples in school context can increase our understanding of the stresses and barriers that chronic ill youth

REVISTA BRASILEIRA DE TERAPIAS COGNITIVAS, 2008, Volume 4, Número 1 
face in school, and what variables can explain moderating or mediating effects in this relationship.

\section{Acknowledgments}

The authors would like to thank The Portuguese Aventura Social e Saúde team, for their work on data collection and data management.

The HBSC study in Portugal in 2001/2004 was funded by FCT/MCT/ 37486/PSI/2001/FEDER and CNLCSida.

\section{References}

American Academy of Pediatrics (1993). Psychological risks of chronic health conditions in childhood and adolescence. Pediatrics, 92(6), 876-878.

Barlow, J. H. \& Ellard, D. R. (2006). The psychosocial well-being of children with chronic disease, their parents and siblings: an overview of the research evidence base. Child: care, health and development, 32 (1), 19-31.

Batista-Foguet, J.; Fortiana, J.; Currie, C. \& Villalbi, J. (2004). Socio-economic indexes in surveys for comparisons between countries. Social Indicators Research, 37 (3), 315-332.

Blum, R.; Kelly, A. \& Ireland, J. (2001). Health-risk behaviours and protective factors among, adolescents with mobility impairments and learning and emotional disabilities. Journal of Adolescent Health, 28, 481-490.

Brannan, A.; Heflinger, C. \& Bickman, L. (1997). The caregiver strain questionnaire: measuring the impact on the family of living with a child with serious emotional. disturbance. Journal of Emotional and Behavioral Disorders, 5(4), 212-222.

Cantril, H. (1965). The pattern of human concern. Piscataway, NJ: Rutgers University Press. Coffey, J. S. (2006). Parenting a child with chronic illness: a metasynthesis. Pediatric Nursing, 32, 51-59.

Combs-Orme, T.; Helfinger, C. A. \& Simpkins, C. (2002). Comorbidity of mental health problems and chronic health conditions in children. Journal of Emotional and Behavioral Disorders, 2, 116-125.

Creer, T. (1982). Asthma. Journal of Consulting and Clinical Psychology, 50, 912-921.

Currie, C.; Hurrelmann, K.; Settertobulte, W.; Smith, R. \& Todd, J. (2000). Health and Health behaviour among young people. HEPCA series (1), Copenhagen: WHO.

Currie, C.; Roberts, C.; Morgan, A.; Smith, R.; Settertobulte, W.; Samdal, O. \& Rassmussen, V. (2004). Young people health in context. Copenhagen: WHO.

Currie, C.; Samdal, O.; Boyce, W. \& Smith, R. (2001). HBSC: a WHO cross national study. Copenhagen: WHO.

Drotar, D. (1997). Relating parent and family functioning to the psychological adjustment of children with chronic health conditions: what have we learned? What do we need to know? Journal of Pediatric Psychology, 22, 149-165.

Edwards, M. \& Davis, H (1997). Counselling children with chronic medical conditions. Leicester, British Psychological Association.

Graham, J.W.; Hofer, S. M. \& Mackinnon, D. P. (1996). Maximizing the usefulness of data obtained

REVISTA BRASILEIRA DE TERAPIAS COGNITIVAS, 2008, Volume 4, Número 1 
with planned missing data patterns, an application of maximum likelihood procedures. Multivariate Behavioral Research, 31, 197-218.

Harbeck-Weber, C. \& McKee, D. (1995). Prevention of emotional and behavioural distress in children experiencing hospitalization and chronic illness. Em: M. Roberts (Org.) Handbook of Pediatric Psychology (pp. 167-184). N.Y.: Guilford.

Jöreskog, K.G. ; Sörbom, D.; du Toit, S. \& du Toit M. (1999). LISREL8: New statistical features. Chicago: Scientific Software International.

Kazak, A. (1992) The social context of coping with childhood chronic illness: family systems and social support. Em: A. LaGreca; L. Sigel; J. Wallander; C. Walker (Orgs.). Stress and coping in child health (pp. 263-278). N.Y.: Guilford.

Matos, M. G. \& Aventura Social (2004). Risco e protecção: o adolescente, os amigos, a família e a escola (Risk and protection: the adolescent, the friends, the family and the school ). Available online from www.fmh.utl.pt/aventurasocial (acessed 18 May 2005).

Miauton, L.; Narring, F. \& Michaud, P. (2003). Chronic illness, life style and emotional health in adolescence: results of a cross sectional survey on the health of 15-20-year-olds in Switzlerland. European Journal of Paediatrics, 152, 682-689.

Miller, A.; Recsky, M. \& Armstrong, R. (2004). Responding to the needs of children with chronic health conditions in an era of health services reform. Canadian Medical Association Journal, 171(11), 1366-1367.

Mukherjee, S.; Lightfoot, J. \& Sloper, P. (2000). The inclusion of pupils with a chronic health condition in mainstream school: what does it mean for teachers? Educational Research, 42(1), 59-72.

Neumark-Sztainer, D.; Story, M.; Resnick, M.; Garwick, A. \& Blum, R. (1995). Body dissatisfaction and unhealthy weight-control practices among adolescents with and without chronic illness: a population-based study. Archives of Pediatric Adolescent Medicine, 149, 1330-1335.

Rao, P.; Pradhan, P. \& Shah, H. (2004). Psychopathology and coping in parents of chronically ill children. The Indian Journal of Pediatrics, 71(8), 695-699.

Sawyer, M.; Reynolds, K.; Couper, J.; French, D.; Kennedy, D.; Staugas, R.; Ziaian, T.\& Baghurst, P. (2004). Health-related quality of life of children and adolescents with chronic illness - a two year prospective study. Quality of Life Research, 13(7). 1309-1319.

Schmoyer, M. (2007). New partners, new tools, new possibilities: views from the fields of education and public health. Preventing Chronic Disease, 4, A44.

Seiffge-Krenke, I. (2001). Diabetic adolescents and their families: stress, coping and adaptation. Cambridge: Cambridge University Press.

Starfield, B. \& Riley, A. (1998). Profiling health and illness in children and adolescents. Em: D. Drotar (Org.) Measuring health-related quality of life in children and adolescents: implications for research and practice (pp. 85-104). Mahwah, New Jersey: Lawrence Erlbaum Associates.

Suris, J. C.; Michaud, P. A. \& Viner, R (2004). The adolescent with a chronic condition. Part I: developmental issues. Archives of Diseases in Childhood, 89, 938-942.

The McCreary Centre Society (1993). Adolescent health survey: chronic illness and disability among youth in B.C. Burnaby; BC: The McCreary Centre Society.

Varni, J. \& Wallander J. (1988). Pediatric chronic disabilities: hemophilia and spina bifida as examples. Em: D. Routh (Org.) Handbook of Pediatric Psychology (pp. 190-221). N.Y.: Guilford.

Wallander, J. (2001). Theoretical and development issues in quality of life for children and

REVISTA BRASILEIRA DE TERAPIAS COGNITIVAS, 2008, Volume 4, Número 1 
adolescents. Em: H. M. Koot \& J. L.Wallander (Orgs.) Quality of life in child and adolescent illness: concepts, methods and findings (pp.23-47). N.Y.: Brunner-Routledge

Wallander, J. \& Varni, J. (1992). Adjustment in children with chronic physical disorders: programmatic research on a disability-stress-coping model. Em: A. LaGreca; L. Sigel; J. Wallander \& C. Walker (Orgs.) Stress and coping in child health (pp. 263-278). N.Y.: Guilford.

Westborn, L. (1992). Well being of children with chronic illness: a population-based study in a Swedish primary care district. Acta Paediatrica, 81: 625-629.

Endereço para correspondência

Endereço do autor principal: Luísa Barros: Faculdade de Psicologia e de Ciências da Educação Universidade de Lisboa. Alameda da Universidade, 1614-013 Lisboa, Portugal.

Email: lbarros@fpce.ul.pt.

Recebido em:18/11/2007

Aceito em: 25/03/2008 